\title{
Model projected heat extremes and air pollution in the eastern Mediterranean and Middle East in the twenty-first century
}

\author{
J. Lelieveld • P. Hadjinicolaou • E. Kostopoulou • \\ C. Giannakopoulos $\cdot$ A. Pozzer $\cdot$ M. Tanarhte $\cdot$ \\ E. Tyrlis
}

Received: 21 March 2012/ Accepted: 11 March 2013/Published online: 24 March 2013

(c) The Author(s) 2013. This article is published with open access at Springerlink.com

\begin{abstract}
The eastern Mediterranean and Middle East, a region with diverse socioeconomic and cultural identities, is exposed to strong climatic gradients between its temperate north and arid south. Model projections of the twenty-first century indicate increasing hot weather extremes and decreasing rainfall. We present model results, which suggest that across the Balkan Peninsula and Turkey climate change is particularly rapid, and especially summer temperatures are expected to increase strongly. Temperature rise can be amplified by the depletion of soil moisture, which limits evaporative cooling, prompted by the waning of large-scale weather systems that generate rain. Very hot summers that occurred only rarely in the recent past are projected to become common by the middle and the end of the century. Throughout the region, the annual number of heat wave days may increase drastically. Furthermore, conditions in the region are conducive for photochemical air pollution. Our model projections suggest strongly increasing ozone formation, a confounding health risk factor particularly in urban areas. This adds to the high
\end{abstract}

Electronic supplementary material The online version of this article (doi:10.1007/s10113-013-0444-4) contains supplementary material, which is available to authorized users.

J. Lelieveld · P. Hadjinicolaou - E. Kostopoulou · A. Pozzer ·

M. Tanarhte $\cdot$ E. Tyrlis

The Cyprus Institute, 1645 Nicosia, Cyprus

J. Lelieveld $(\bowtie) \cdot$ A. Pozzer $\cdot$ M. Tanarhte

Max Planck Institute for Chemistry, 55020 Mainz, Germany

e-mail: jos.lelieveld@mpic.de

E. Kostopoulou

University of the Aegean, 81100 Mytilene, Greece

C. Giannakopoulos

National Observatory of Athens, 15236 Athens, Greece concentrations of aerosol particles from natural (desert dust) and anthropogenic sources. The heat extremes may have strong impacts, especially in the Middle East where environmental stresses are plentiful.

Keywords Climate change - Heat extremes - Ozone · Air pollution · Urban environment · Middle East . Eastern Mediterranean

\section{Introduction}

Climate gradients in the eastern Mediterranean and Middle East (EMME) can be very pronounced (Issar and Zohar 2007; Lionello et al. 2006). Given the proximity of the EMME to the Indian and Atlantic Oceans and the extensive land areas of Eurasia and Africa, associated with contrasts between maritime and continental air masses and diverse meteorological characteristics, it is at the crossroads of many global weather and climate patterns. A large fraction of the annual precipitation in the area falls during winter, often related to major North Atlantic synoptic systems, promoted by low-level baroclinicity and moisture from the Mediterranean Sea and modulated by the local orography (Krichak et al. 2007; Lionello et al. 2006). During spring, the mid-latitude zone of baroclinicity retreats northwards, and in summer, the region is subject to tropical influences, primarily the South Asian monsoon, leading to enhanced subsidence which suppresses clouds and rain (Alpert et al. 2005; Rodwell and Hoskins 1996; Tyrlis et al. 2013). Data analyses and climate model projections suggest an overall drying and warming of the region, especially in summer (Christensen et al. 2007; Evans 2009, 2010; Gao and Giorgi 2008; Kitoh et al. 2008; Lelieveld et al. 2012; Önol and Semazzi 2009; Tanarhte et al. 2012). This is 
accompanied by enhanced risks of heat extremes, which are the focus of the current study.

Heat waves can have profound impacts on human health, power systems, economies, ecosystems and agriculture (Battisti and Naylor 2009; Beniston et al. 2007; Haines et al. 2006). Mortality rates can more than double due to cardiovascular, cerebrovascular and respiratory ailments, while infants and the elderly bear the greatest risk (Anderson and Bell 2011; Knowlton et al. 2009). Cities are most strongly affected because of the accumulation of air pollution under stagnant meteorological conditions and other confounding health risk factors (Basu and Samet 2002; Fischer et al. 2012; Knowlton et al. 2004). In summer 2003, an extensive heat wave hit large parts of Europe. Average summer temperatures were about $3{ }^{\circ} \mathrm{C}$ higher than the long-term mean, and in major cities, the daily maximum temperature exceeded $35{ }^{\circ} \mathrm{C}$ for more than a week, causing about 70,000 excess deaths in parts of southern, western and central Europe (Robine et al. 2006; Schär et al. 2004; Vandentorren et al. 2006). Global and regional climate model simulations suggest that heat waves will increase in particular in southern Europe (Diffenbaugh et al. 2007; Meehl and Tebaldi 2004; Fischer and Schär 2010). Here, we extend these studies to the EMME, based on climate and atmospheric chemistry model projections for the twenty-first century, focusing on heat extremes and air pollution in metropolitan areas.

\section{Methods}

We used the regional climate model PRECIS (Providing Regional Climates for Impact Studies) at $0.22^{\circ}$ latitude/ longitude, that is, $\sim 25-\mathrm{km}$ grid resolution (Jones et al. 2004). It applies the same formulation of the climate system as its parent atmosphere-ocean general circulation model, HadCM3, which provides the lateral boundary conditions (Collins et al. 2006). The PRECIS model describes the dynamical flow, the atmospheric sulfur cycle, clouds and precipitation, radiative processes, the land surface and the deep soil (Jones et al. 2004). The sulfur cycle has been included to account for the direct effects of sulfate aerosols on climate through the scattering of solar radiation. The version of PRECIS used includes the Met Office Surface Exchange System (MOSES), which represents soil and vegetation processes and calculates energy, moisture and $\mathrm{CO}_{2}$ fluxes (Cox et al. 1999; Zittis et al. 2013).

We simulated climate conditions in the EMME over the period 1950-2099 driven by the Special Report on Emissions Scenarios (SRES) intermediate scenario A1B, accounting for greenhouse gases, including ozone, and sulfate aerosols. The emission scenarios A1B, A2 and B2 applied in the PRECIS model have been developed for the
Intergovernmental Panel on Climate Change, described by Nakićenović and Swart (2000) (see also http://en.wiki pedia.org/wiki/Special_Report_on_Emissions_Scenarios). We also performed sensitivity simulations based on the SRES emission scenario B2 with relatively low greenhouse gas emissions and the A2 scenario with relatively high emissions for the period 2070-2099. The results for the future are contrasted to those obtained for the reference period 1961-1990.

We compared the PRECIS output to observations of recent climate conditions and found that the model realistically simulates observed weather patterns and indices of extremes. For example, the mean number of days per year with maximum temperatures above $25{ }^{\circ} \mathrm{C}$ agrees within about $\pm 10 \%$ with meteorological data since 1950 , and the number of consecutive dry days per year matches the analyses of observations within about $\pm 15 \%$ (Lelieveld et al. 2012). We used the model to calculate temperature trends for the period 2000-2099 and changes in heat waves for the three scenarios. The heat wave day index (HWD90) is defined as a spell of at least six consecutive days with maximum temperatures exceeding the local 90th percentile of the reference period. It is calculated using the RClimDex software of X. Zhang, as mentioned by Klein Tank et al. (2009) and applied by Zhang et al. (2005) and Klok and Klein Tank (2009). Although we also present results for the 95th and 99th percentile, HWD95 and HWD99, respectively, we focus on HWD90 because only for this metric observational data are available to compare with the model results.

It should be emphasized that even though the model does not explicitly resolve metropolitan areas, hot weather is related to synoptic-scale conditions which are generally well represented. The calculated daytime maximum temperatures (TX) in the EMME agree well with observations collected in the Climatic Research Unit (CRU) TS3.0 dataset until the year 2005 (Lelieveld et al. 2012; Mitchell and Jones 2005). Note that this CRU dataset has been compared to other meteorological datasets available for the region, and outliers and inconsistencies were not detected, in contrast to other datasets (Tanarhte et al. 2012). The PRECIS predictions are consistent with other climate projections as the results of the parent global model (HadCM3) are well within those of the ensemble mean of the 23 atmospheric-ocean general circulation models of the Intergovernmental Panel on Climate Change (IPCC) (Meehl et al. 2007). Kharin et al. (2007) analyzed the weather extremes calculated by the global climate models participating in the IPCC Fourth Assessment Report and concluded that the models simulate present-day warm extremes reasonably well compared to meteorological re-analysis data. Furthermore, the PRECIS results are qualitatively consistent with those of previously published 
high-resolution climate model studies (Evans 2010; Kitoh et al. 2008; Krichak et al. 2011; Önol and Semazzi 2009; Smiatek et al. 2011).

To test the performance of PRECIS against other regional climate models, we computed changes in TX for 12 capital cities in the EMME between the reference period 1961-1990 and 2021-2050 and compared with the ensemble mean of nine regional climate models (Fig. 1). The comparison is limited to the eastern Mediterranean and the period 2021-2050 because the projects ENSEMBLES (http://www.ensembles-eu.org/) and CIRCE (Climate
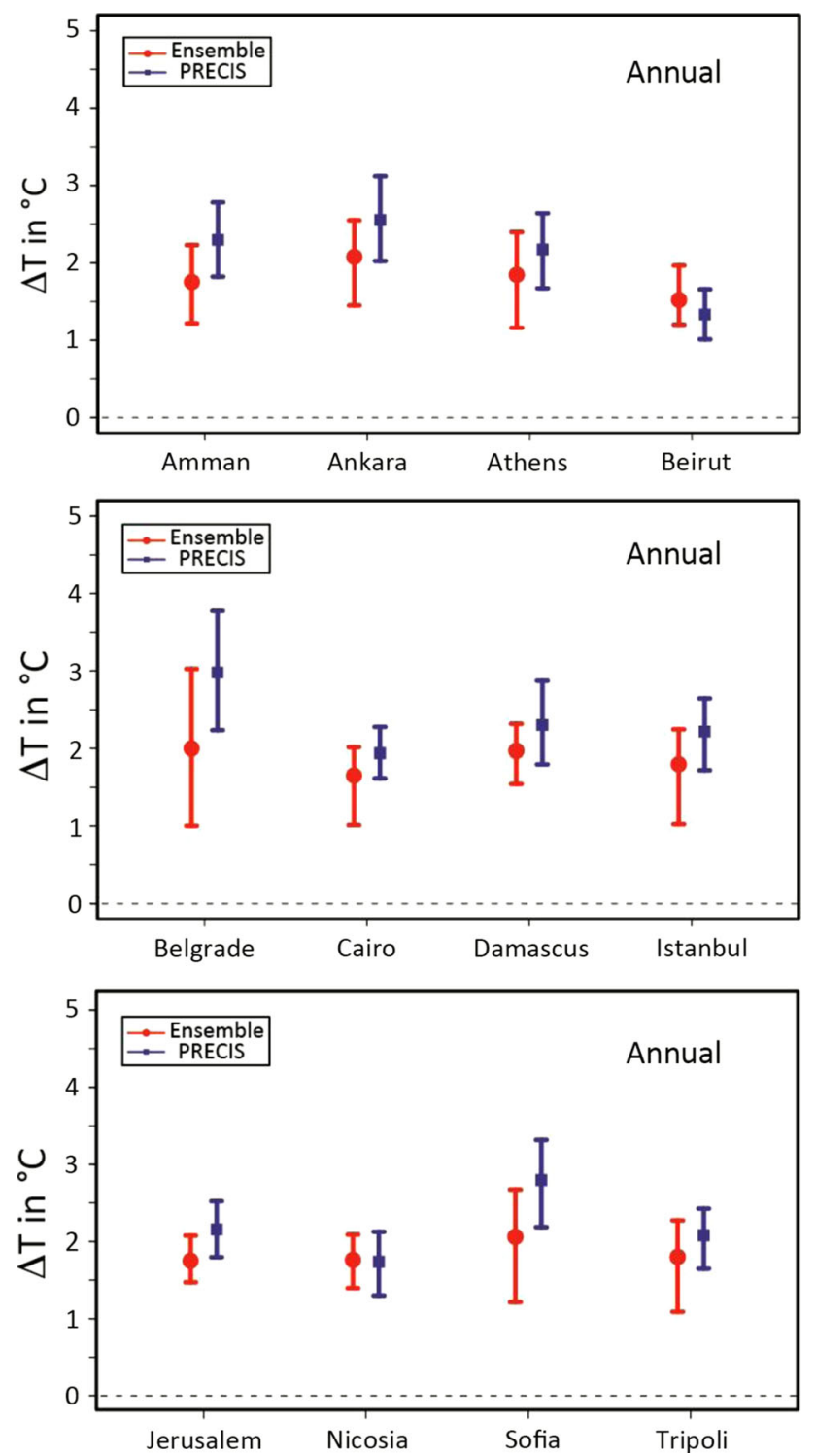

Fig. 1 PRECIS output (blue) compared to that of the nine-model ensemble mean (red). Annual average changes in daytime maximum temperature (TX) between the periods 1961-1990 and 2021-2050 for 12 metropolitan centers in the EMME region. The multi-model means and standard deviations were calculated by regional European climate models applying the A1B emission scenario
Change and Impact Research: The Mediterranean Environment, http://www.circeproject.eu/), for which these calculations have been performed, focused on the European-Mediterranean domain, and they did not extend beyond 2050 (Gualdi et al. 2011; Kjellström and Giorgi 2010). The model inter-comparison indicates that the PRECIS results overlap with the ensemble mean. The model inter-comparison indicates that the PRECIS results are generally within the range of the ensemble mean. In addition to Fig. 1, this is illustrated in Figure $\mathrm{S} 1$ in the Supplementary Data, showing the annual and seasonal mean TX changes for 12 cities throughout the region. However, especially in summer (June-August), the maximum temperatures tend toward the high end of the multimodel spread, possibly indicating a warm bias, especially in the northern part of the model domain, for example, in Belgrade and Sofia. Nevertheless, the PRECIS results agree very well with the ensemble mean in autumn, winter and spring (Figure S1), while the model simulation of relatively warm summers leads to a slight warm bias in the annual mean (Fig. 1).

Further, we employed the ECHAM5/MESSy Atmospheric Chemistry (EMAC) general circulation model to investigate changes in the regional air quality (Jöckel et al. 2005; Roeckner et al. 2006; Sander et al. 2005). Extensive model evaluations have been performed based on in situ and remote sensing observations (Jöckel et al. 2006; Pozzer et al. 2007, 2010; Tost et al. 2007; Pringle et al. 2010; Liu et al. 2011). The model has been used at T106L31 resolution, corresponding to a latitude $\times$ longitude grid spacing of about $1.1^{\circ} \times 1.1^{\circ}$ and a vertical resolution of 31 levels up to $10 \mathrm{hPa}$ in the lower stratosphere. The model setup used in this work has been described and evaluated by Pozzer et al. (2012a) for the year 2005, which we use as a baseline simulation.

We also simulated a future air quality scenario for 2050, comparable to the SRES scenario A1B (Pozzer et al. 2012b). The emission scenario includes nitrogen oxides $\left(\mathrm{NO}_{\mathrm{x}}\right)$, carbon monoxide $(\mathrm{CO})$, non-methane volatile organic compounds (NMVOCs), ammonia $\left(\mathrm{NH}_{3}\right)$, sulfur dioxide $\left(\mathrm{SO}_{2}\right)$, black carbon (BC) and particulate organic matter (POM) from fossil fuel and biofuel combustion, industrial processes and the production and usage of solvents, agriculture and waste treatment. The emission totals of all countries in the base year 2005 were projected up to 2050. Comparable to Shindell et al. (2012), the projections differentiate between climate change and air pollution control measures because the implementation of the former requires a longer process of structural changes compared to the latter. The scenario assumes that no additional emission control measures are taken beyond those implemented in 2005. The future emissions of pollutants lead to a stabilization of present-day air quality. For example, the 
projected global $\mathrm{CO}$ and $\mathrm{BC}$ emissions for the year 2050 are 559 and $5.4 \mathrm{Tg} /$ year, respectively, being 4.7 and $8.4 \%$ less compared to those in 2005.

Beyond 2005, no change in technologies for combustion (power industry, transport), industrial processes (steel, cement, chemicals), waste treatment and agriculture is assumed. Either the activity data or the emission factors are scaled up. Nevertheless, improvements in energy efficiency of the technologies already in place in the year 2005 are expected for the projected years. The solvent-related activities are driven only by population, while the energyrelated activities are driven by population and economic growth, following the projected oil, gas and coal markets for the different world regions (Pozzer et al. 2012a, b). This assumes a continuation of the trend from 1990 to 2005, hence the energy consumption relative to the GDP is assumed to decline further, which is more than offset by economic growth and is projected to be $79 \%$ above 2005 levels by 2050 .

The fossil fuels dominate $(75 \%)$ the fuel mix until 2030 , and then, they are expected to decrease by $10 \%$ assuming that renewable and nuclear power will grow. These assumptions are in line with those incorporated in world energy models from the International Energy Agency (IEA) World Energy Outlook 2006. The agriculture-related activities are mainly driven by population and corresponding food demand and follow the projected global agricultural trade with regional food prices and with livestock cropland. The global agricultural production is assumed to grow by more than $50 \%$ through increased productivity and an extension of the agricultural area with about $10 \%$ (Pozzer et al. 2012b).

It should be emphasized that these air quality model calculations do not account for climate change, and the comparison between the results for 2005 and 2050 is based on differences in atmospheric composition only. Preferably, the air quality and climate change calculations should be performed with an online coupled regional chemistryclimate model. Since such models that also include comprehensive representations of atmospheric chemistry and aerosols are not commonly available, also because computational costs are prohibitive, recent studies have used offline regional air quality models (Jiménez-Guerrero et al. 2012) or statistical relationships between air pollution and meteorological variability related to meteorological fields projected by global climate models (Tai et al. 2012). The effects of climate change on air quality found in these studies are relatively small. The largest impacts are expected from the changing emissions of biogenic compounds (Langner et al. 2012; Young et al. 2013), being insignificant in the region considered here, and of dust emissions. Since we apply our global model at relatively high resolution and focus on anthropogenic air pollution we expect that inconsistencies between our regional and global models are not significant.

\section{Results and discussion}

Tables 1 and 2 present the model-calculated temperature trends and the projected future changes of high temperature extremes at 18 major metropolitan locations in the eastern Mediterranean and Middle East. For comparison, Table 2 also includes observations (Klok and Klein Tank 2009; Zhang et al. 2005). For the cities Baghdad (at $33.3^{\circ} \mathrm{N}$, $44.4^{\circ} \mathrm{E}$ ) and Damascus (at $33.5^{\circ} \mathrm{N}, 36.3^{\circ} \mathrm{E}$ ), the nearby stations of Kut-Al-Hai $\left(32.2^{\circ} \mathrm{N}, 46.1^{\circ} \mathrm{E}\right)$ and Mafraq $\left(32.4^{\circ} \mathrm{N}, 36.3^{\circ} \mathrm{E}\right)$ have been used, respectively. The Iranian city Abadan is included because it is located in the Arabian Gulf region for which observations are otherwise scarce. Table 1 indicates that in the northern EMME, TX generally increases more rapidly than the mean temperature TM (e.g., Ankara, Belgrade, Damascus, Sofia, Tehran, Tirana), which we attribute to atmosphere-surface feedbacks, as discussed in more detail below. In the southern EMME, the daily minimum temperature $\mathrm{TN}$ increases more rapidly than TM (e.g., Baghdad, Cairo, Riyadh, Tripoli and along the Arabian Gulf) related to an increase in cloudiness, which reduces nighttime radiative cooling.

Figures 2 and 3 show model projections of daytime maximum (TX) and nighttime minimum (TN) temperature during summer by the middle and the end of the twentyfirst century. They also show the 95-percentile confidence ranges obtained by bootstrapping (Giannakopoulos et al. 2009). The ranges in the lower panels are the differences between the upper and lower confidence limits. For example, our analysis indicates $95 \%$ confidence that the rise in TX by the end of the century will be between $3.5 \pm 0.4$ in southern Iran and $7 \pm 1.3{ }^{\circ} \mathrm{C}$ in the northern Balkan region, that is, varying with subregion, signifying

Table 1 Linear trends (in ${ }^{\circ} \mathrm{C} /$ decade) in the period 2000-2099 from model output of the mean nighttime minimum (TN), the mean (TM) and the daytime maximum temperature (TX)

\begin{tabular}{lccclccc}
\hline City & TN & TM & TX & City & TN & TM & TX \\
\hline Abadan & 0.48 & 0.46 & 0.44 & Istanbul & 0.46 & 0.45 & 0.46 \\
Amman & 0.44 & 0.45 & 0.45 & Jerusalem & 0.44 & 0.44 & 0.44 \\
Ankara & 0.45 & 0.47 & 0.49 & Kuwait City & 0.45 & 0.42 & 0.41 \\
Athens & 0.48 & 0.46 & 0.46 & Nicosia & 0.42 & 0.41 & 0.41 \\
Baghdad & 0.48 & 0.47 & 0.46 & Riyadh & 0.50 & 0.46 & 0.43 \\
Beirut & 0.35 & 0.35 & 0.35 & Sofia & 0.47 & 0.49 & 0.53 \\
Belgrade & 0.48 & 0.49 & 0.51 & Tehran & 0.44 & 0.44 & 0.54 \\
Cairo & 0.45 & 0.43 & 0.41 & Tirana & 0.48 & 0.48 & 0.52 \\
Damascus & 0.45 & 0.46 & 0.48 & Tripoli & 0.43 & 0.41 & 0.41 \\
\hline
\end{tabular}


Table 2 Heat wave days index (HWD90) based on observations (Klok and Klein Tank 2009; Zhang et al. 2005) and model output for different time periods and the emission scenarios A1B, A2 and B2

\begin{tabular}{|c|c|c|c|c|c|c|c|c|}
\hline City & $\begin{array}{l}\text { Period of } \\
\text { observations }\end{array}$ & Observed & $\begin{array}{l}\text { Model } \\
1961-1990\end{array}$ & $\begin{array}{l}\text { Model A1B } \\
\text { 2010-2039 }\end{array}$ & $\begin{array}{l}\text { Model A1B } \\
\text { 2040-2069 }\end{array}$ & $\begin{array}{l}\text { Model A1B } \\
\text { 2070-2099 }\end{array}$ & $\begin{array}{l}\text { Model A2 } \\
\text { 2070-2099 }\end{array}$ & $\begin{array}{l}\text { Model B2 } \\
\text { 2070-2099 }\end{array}$ \\
\hline Abadan & $1951-2000$ & 10 & 9 & 33 & 79 & 112 & 121 & 72 \\
\hline Amman & 1959-2004 & 7 & 8 & 23 & 62 & 102 & 107.5 & 55.5 \\
\hline Ankara & $1951-2003$ & 12 & 10.5 & 33.5 & 70.5 & 128.5 & 124 & 73 \\
\hline Athens & $1951-2001$ & 13.5 & 13.5 & 26.5 & 76.5 & 135.5 & 147 & 88 \\
\hline Baghdad & $1950-2000$ & 10 & 11.5 & 42.5 & 98.5 & 131.5 & 149 & 86 \\
\hline Beirut & $1951-2010$ & 6 & 11 & 38 & 99 & 142 & 173 & 130 \\
\hline Belgrade & 1980-2001 & 13 & 13.5 & 26.5 & 43.5 & 94.5 & 100.5 & 59.5 \\
\hline Cairo & - & - & 7.5 & 22.5 & 56.5 & 90.5 & 82.5 & 52.5 \\
\hline Damascus & 1965-1993 & 19 & 9 & 29 & 77 & 114 & 123 & 63 \\
\hline Istanbul & $1951-2010$ & 7 & 6.5 & 20.5 & 52.5 & 100 & 100.5 & 59.5 \\
\hline Jerusalem & 1964-2004 & 12 & 11.5 & 20.5 & 51.5 & 84.5 & 85.5 & 50 \\
\hline Kuwait & - & - & 7.5 & 31.5 & 86.5 & 138.5 & 166.1 & 103 \\
\hline Nicosia & 1975-2001 & 7 & 10.5 & 19.5 & 59.5 & 91.5 & 149 & 86 \\
\hline Riyadh & 1970-2004 & 8 & 12 & 59 & 129 & 170 & 202 & 155 \\
\hline Sofia & 1960-2010 & 13 & 11 & 23 & 57.5 & 101.5 & 120 & 77 \\
\hline Tehran & 1956-1999 & 7 & 12 & 43 & 89 & 127 & 151.5 & 98.5 \\
\hline Tirana & $1951-2000$ & 10.5 & 11.5 & 27.5 & 77.5 & 126.5 & 149 & 104 \\
\hline Tripoli & 1956-1990 & 12 & 8 & 10 & 23 & 40 & 51 & 29.5 \\
\hline
\end{tabular}

Unit is the median number of days per year

Model results for the same period refer to equal time intervals, sometimes fragmentary, for which observations are available

an uncertainty range of about $15 \%$ (similar for $\mathrm{TN}$ ). In the northern EMME, from Italy, the Balkans, Turkey, Georgia up to southern Russia, TX increases very steeply up to $4-5{ }^{\circ} \mathrm{C}$ by mid-century and $5-7^{\circ} \mathrm{C}$ by the end of the century; more strongly than $\mathrm{TN}$.
The latter is a consequence of a decrease in cyclonic weather events, notably in the spring transition season when the baroclinic zone weakens rapidly. The weakening of the Mediterranean storm track may be considered a robust result of climate change studies, based on
Fig. 2 Changing daytime maximum temperature TX (a, b) and the 95 percentile confidence ranges

(c, d) averaged over June-JulyAugust, for the periods 2040-2069 (a, c) and 2070-2099 (b, d) relative to the period 1961-1990. Model calculations are for the A1B scenario
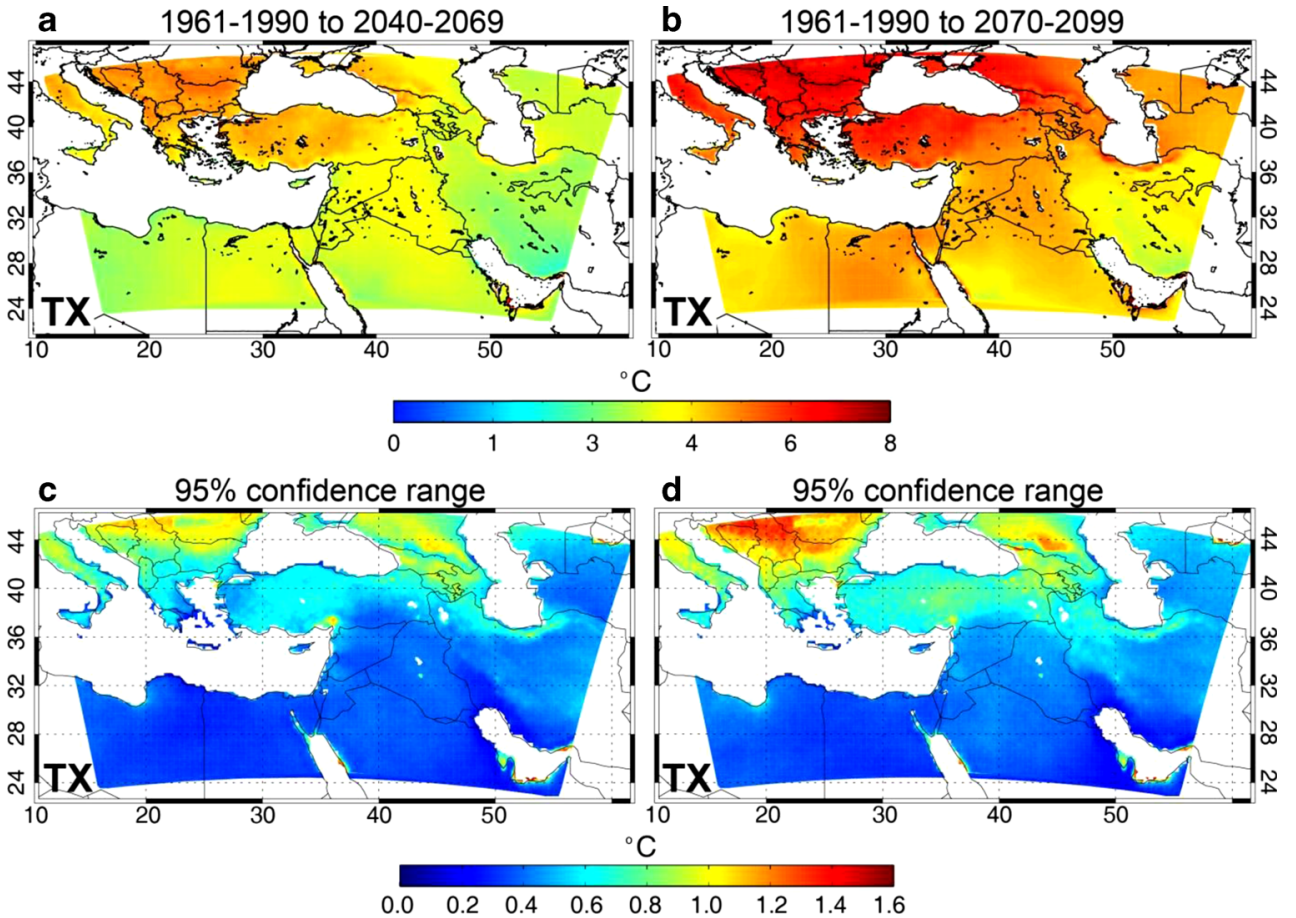
Fig. 3 Changing nighttime minimum temperature $\mathrm{TN}$ (a, b) and the 95 percentile confidence ranges $(\mathbf{c}, \mathbf{d})$, averaged over June-JulyAugust, for the periods 2040-2069 (a, c) and 2070-2099 (b, d) relative to the period 1961-1990. Model calculations are for the A1B scenario
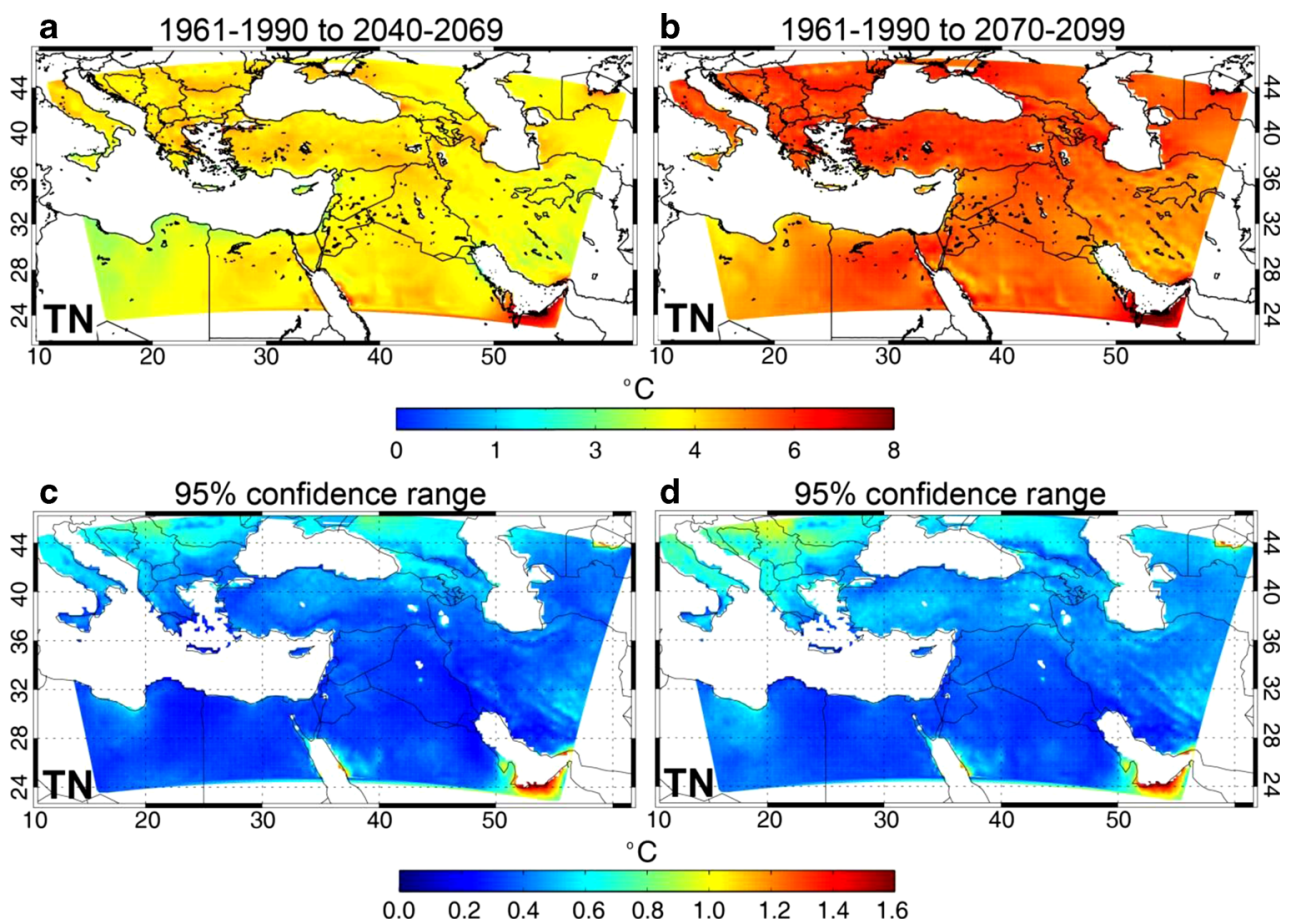

observations and model projections (Bengtsson et al. 2006; Trigo et al. 2000; Ulbrich et al. 2009). Consequently, the cloud cover decreases, which enhances solar radiation absorption at the surface and increases TX. This accelerates evaporation and promotes the depletion of soil moisture, which is also influenced by a general decrease in the relative humidity. In turn, this reduces evaporative cooling, which is balanced by sensible heating. Since the soil moisture reservoir can act as a "memory" of precipitation anomalies for weeks to months, the effect persists into the summer (Seneviratne et al. 2010; Zittis et al. 2013). We refer to Zittis et al. (2013) for a more in depth analysis.

This positive feedback mechanism through soil moisture has been proposed as an important cause of heat stress intensification, including the European heat wave in 2003 (Diffenbaugh et al. 2007; Vautard et al. 2007). Its importance is corroborated by direct observational evidence in southeastern Europe (Hirschi et al. 2011) and indirectly by the observed increase in heat waves in the Balkans and Turkey (Kuglitsch et al. 2010). Further north this mechanism is less relevant since precipitation either declines less or increases, and temperatures are lower, whereas further south the soils are barren anyhow. In the region around the Arabian Gulf, we actually find a reverse tendency, as the model predicts that clouds and precipitation increase. This is a consequence of the expanding influence from the humid tropics (Evans 2009, 2010). The increasing cloudiness moderates the trend in TX and increases it in TN by limiting radiative cooling during the night. This explains why TN increases more uniformly throughout the EMME than TX. The lack of nighttime cooling in this region can actually exacerbate the impact of heat waves.

Even though the Gulf States may expect increasing precipitation, the absolute amounts are small and the model predicts an overall regional rainfall reduction throughout the domain of $10-25 \%$ by $2040-2069$, up to about $30 \%$ by 2070-2099, mostly in the eastern Mediterranean, Greece, southern Turkey, the coastal Levant and North Africa, similarly as projected by previous studies (Evans 2009, 2010; Gao and Giorgi 2008; Kitoh et al. 2008; Önol and Semazzi 2009). This implies, for example, that by 2040-2069, the discharges of the Tigris-Euphrates and Jordan River systems will decrease by about 10 and 20-25\%, respectively, with further decreases by the end of the century (Önol and Semazzi 2009; Chenoweth et al. 2011). By also accounting for population growth rates, the per capita available internal water resources in several countries may decline strongly. In Jordan, Cyprus and Syria, they may fall by $50 \%$ or more by mid-century, and substantial decreases are also expected for Greece, Lebanon, Israel and the Palestine territories (Chenoweth et al. 2011).

Our model results suggest important changes in heat extremes. In view of the particularly harmful effects of heat waves in cities, we focus on the main capitals in the region. In the EMME, most people live in the urban environment and more than $20 \%$ in cities with more than one million inhabitants. A classification of heat waves must relate high temperatures to local conditions to which indigenous populations are accustomed and have adapted. Accordingly, the heat wave days HWD90 index is defined relative to the local 
temperature regime during the reference period 1961-1990 (Fischer and Schär 2010; Zhang et al. 2005). Clearly, the dangers of dehydration and hyperthermia, when the body is unable to dissipate its metabolic heat, are highest in areas where summers are hottest. In parts of the Middle East, for example, mean summer temperatures close to the human body temperature of $37{ }^{\circ} \mathrm{C}$ are already common.

Our model calculations for the twenty-first century predict strong mean temperature trends in all major cities, varying between 0.35 and $0.49{ }^{\circ} \mathrm{C}$ per decade (Table 1). Relatively strong trends are projected to occur in inland locations such as Ankara, Baghdad, Belgrade, Damascus, Riyadh and Sofia where the annual mean temperature increases more than $0.4{ }^{\circ} \mathrm{C}$ per decade. Smaller trends are calculated at coastal and island locations, such as Beirut, along the Arabian Gulf, Nicosia and Tripoli. The results indicate that the trends of warm extremes typically follow those of the mean summertime temperatures. An important aspect of the growing occurrence of heat extremes in the EMME is that the summer temperatures increase relatively strongly, that is, more rapidly than in winter. This contrasts with model predictions for central and northern Europe where temperatures are expected to rise more strongly in winter instead (Christensen et al. 2007). Therefore, the relatively steep increase in the maximum temperature TX in summer and the number of heat wave days is remarkable but perhaps not surprising.

In Section 11.3 of IPCC (2007), the relatively strong increase in summer temperatures in the Mediterranean area is classified as "likely" based on climate change projections by global and regional models. Figure 4 and Table 2 (also Figures S2 and S3) show that the rising temperatures are associated with sharp increases in the number of heat wave days HWD90, notably since 1990, in agreement with observations from the 1950s up to the early 2000s (Efthymiadis et al. 2011; Zhang et al. 2005). It should be noted that the PRECIS projections of TX in summer tend toward the high end of the ranges derived from the ensemble mean of nine regional European climate models, as shown in Figs. 1 and S1. This pertains in particular to locations in the Balkans and the Anatolian Peninsula, where the positive feedback between reduced precipitation and the loss of soil moisture is expected to be most relevant. Therefore, it cannot be ruled out that our results are to some degree model dependent and may overestimate the summertime heating anomalies.

The PRECIS results also suggest a general increase in the inter-annual variability, which can add substantially to the intensity of heat extremes (Fischer and Schär 2010; Schär et al. 2004). The number of heat wave days typically increases by a factor of $4-10$ by the middle and $7-15$ by the end of the century, with the strongest increases in the Middle East. Tables S1 and S2 also present calculations for stricter definitions of heat extremes to account for the exceeding of local 95th and 99th percentiles (HWD95 and
HWD99), which indicates similar rates of increase. Sensitivity simulations based on different greenhouse gas emission assumptions suggest that the more pessimistic scenario A2 further enhances the number of heat wave days compared to the A1B projections, though not very strongly in all cities. The more optimistic scenario B2 substantially reduces their number by 30-50\%, though they are still strongly enhanced compared to the reference period (right panels of Fig. 4 and Figure S3).

Our results for the A1B scenario suggest that by the end of the century, the frequency of very hot days $\left(\mathrm{TX}>35^{\circ} \mathrm{C}\right)$ may increase up to 1-2 weeks per year in mountainous parts of the northern EMME and by about a month in much of the rest of the region. The strongest increases appear in the coastal Levant and North Africa ( $>2$ months/year). The frequency of "tropical" nights $\left(\mathrm{TN}>25{ }^{\circ} \mathrm{C}\right)$ also increases strongly, by nearly a month per year in the Balkans and coastal areas, and more than two months in the Gulf region, exacerbating the daytime heat stress. A measure of seasonal heat extremes is the frequency distribution of TX anomalies in summer. Figure 5 suggests that by the end of the century in most cities, the coolest summers may be warmer than the hottest ones during the reference period, which appears to be the case for all three scenarios considered (Figure S4).

Figure S4 presents additional frequency histograms for three emission scenarios and the 18 cities, corroborating that even the relatively optimistic scenario B2 is associated with strong changes in TX. The TX anomalies under scenario A2 are even larger, with significant frequencies of TX increasing up to $10^{\circ} \mathrm{C}$ in several cities. Furthermore, especially in the Middle East, the environmental stress is aggravated by deteriorating air quality, associated with the strong growth of population, traffic and economic development. This includes several megacities such as Teheran, Istanbul and Cairo. The latter is among the megacities with poorest air quality worldwide, leading to an estimated excess mortality of about $14,000 /$ year in the past decade (Gurjar et al. 2010). The regional meteorological conditions are conducive of photochemical air pollution, sometimes leading to extraordinary high levels of ozone and airborne desert dust (Smoydzin et al. 2012). In contrast to most of Europe, air pollution is increasing strongly in the Middle East, augmented by rising temperatures, decreasing removal by rain and the emergent fossil energy consumption for air conditioning and desalination.

The combination of anthropogenic air pollution with the abundant desert dust in the region leads to an extensive haze, especially in summer when removal by rain is inefficient. The annual mean particulate mass concentrations, calculated for the year 2005, reach up to $100 \mu \mathrm{g} / \mathrm{m}^{3}$ in the Middle East and higher over North Africa, whereas in southern Europe and over Turkey, they are typically $20-30 \mu \mathrm{g} / \mathrm{m}^{3}$. The levels are highest in the urban environment, often exceeding the 

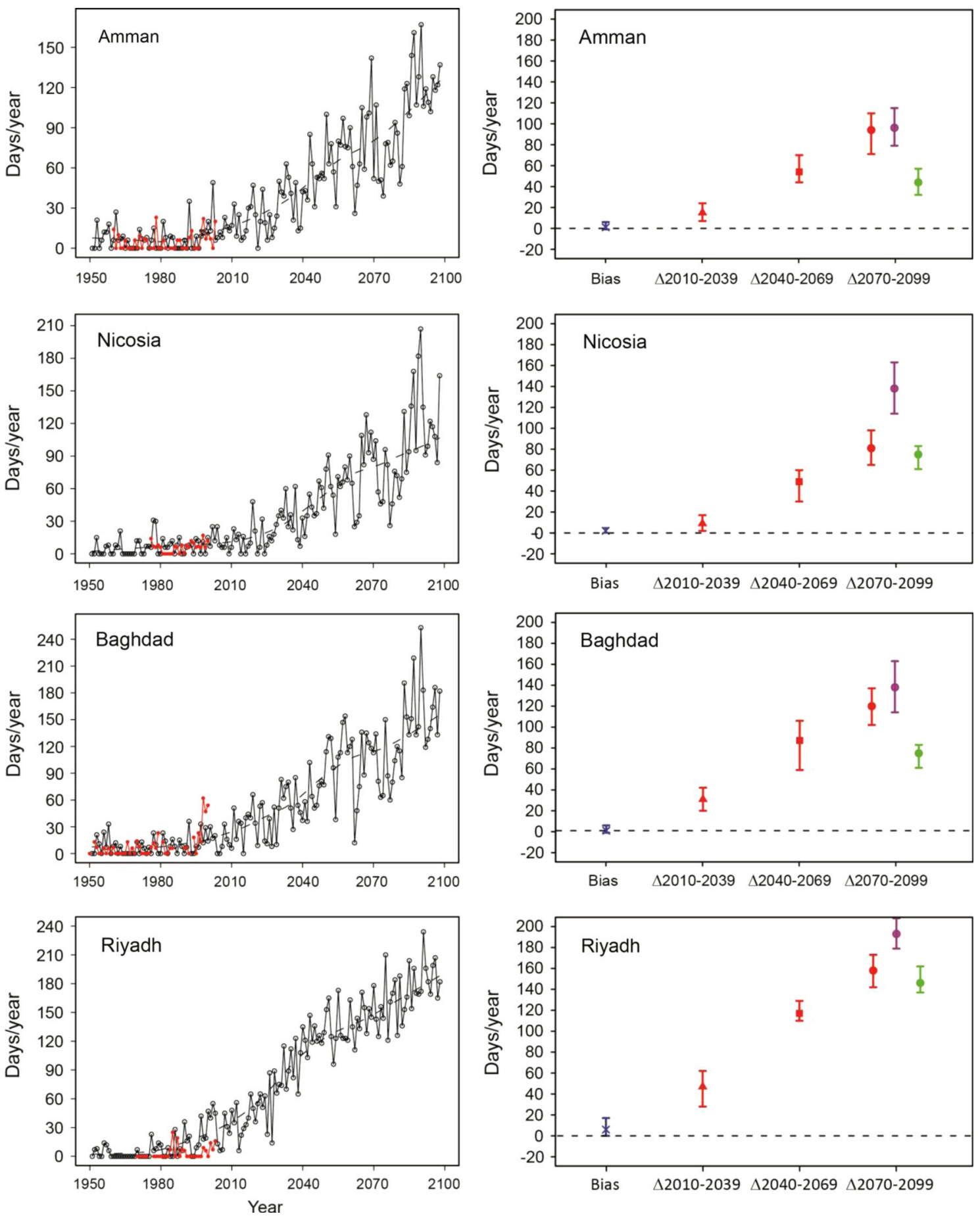

Fig. 4 Growing number of heat wave days per year. Left time series of HWD90 based on observations (in red) and model calculations based on the A1B scenario (open circles). Right biases between modeled and observed HWD90, and increases in HWD90 between

European air quality standard for annual mean particulate matter $\left(\mathrm{PM}_{2.5}\right)$ of $25 \mu \mathrm{g} / \mathrm{m}^{3}$ (http://ec.europa.eu/environme nt/air/quality/standards.htm). Recent trends of aerosol particles over most of the Mediterranean, downwind of Europe, are negative, whereas they are positive over Turkey and the

three future periods and 1961-1990. The error bars around the mean values indicate the $95 \%$ confidence levels. The results for the emission scenarios A1B, B2 and A2 are indicated in red, green and purple, respectively. For additional cities, see Figures S2 and S3

Middle East (Papadimas et al. 2009; de Meij et al. 2012). Although the aerosol mass concentrations in the EMME are dominated by desert dust, our model calculations suggest that the contribution to fine particulates by air pollution will increase significantly (Pozzer et al. 2012b). 

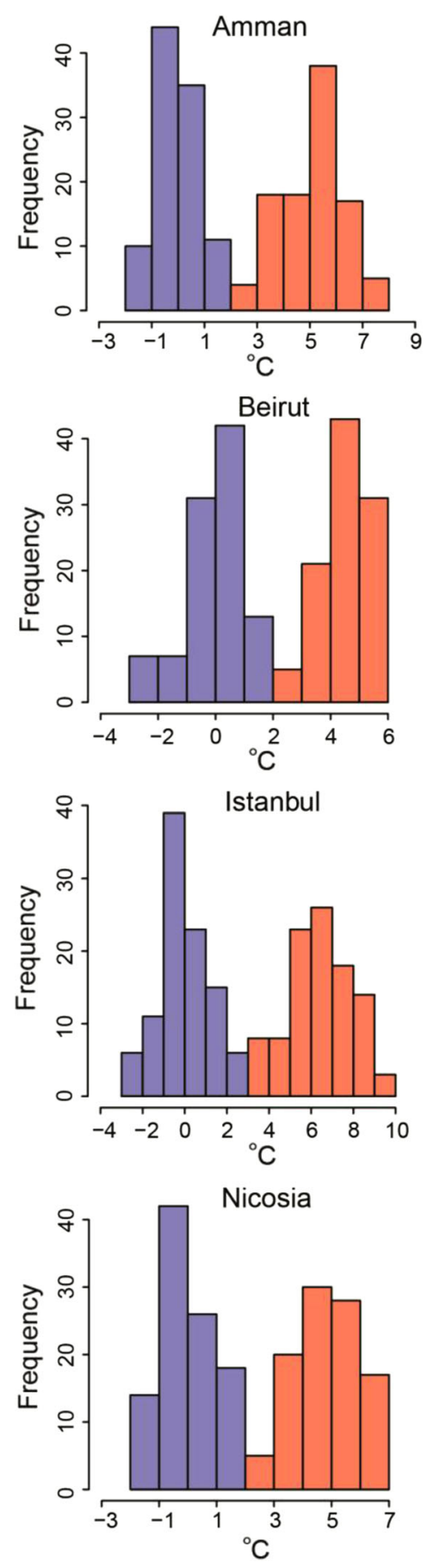

Fig. 5 Recent and end of the century temperature anomalies. Modelcalculated frequency histograms (\%) of summer (JJA) daytime maximum temperature (TX) anomalies relative to the period

Figure 6 presents model-calculated frequency distributions of ozone mixing ratios during summer in major capitals in the EMME, both for 2005 and 2050. Clearly, in 2005 and in particular in 2050, the 8-hourly EU air quality standard of about $60 \mathrm{ppbv}$ is exceeded regularly (http://ec. europa.eu/environment/air/quality/standards.htm). Whereas in many cities, such as Ankara, Athens, Beirut, Istanbul,
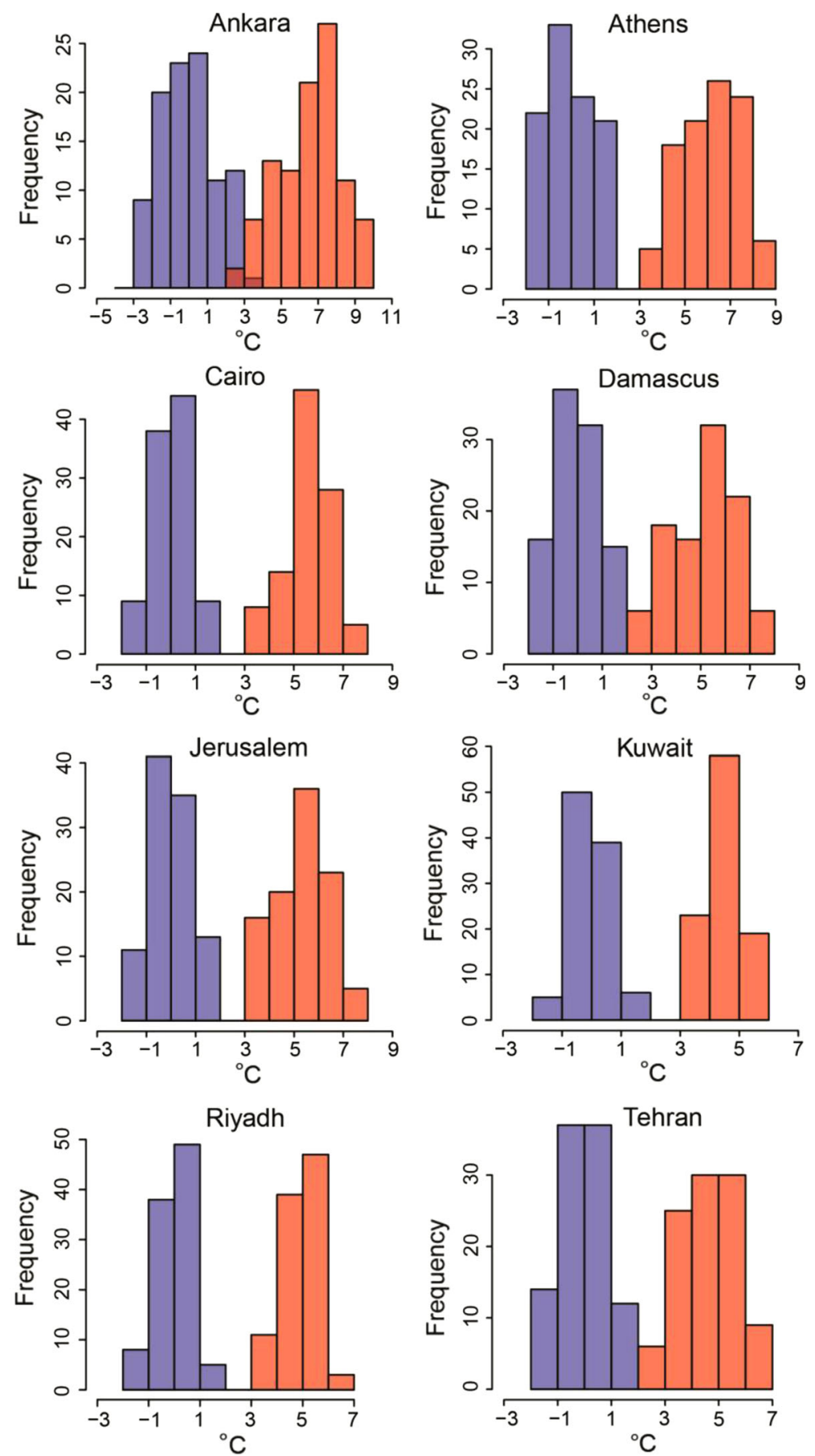

1961-1990, based on the A1B scenario. Blue is for the period 1961-1990 (hence centered around $0{ }^{\circ} \mathrm{C}$ ) and red for the period 2070-2099. For additional cities and scenarios, see Figure S4

Nicosia and Tehran, the peaks of the distribution were around $60 \mathrm{ppbv}$ in the recent past, they are projected to shift to much higher values in future. While in many cities in the EMME high ozone values in summer are already typical (Lelieveld et al. 2009), it appears that by the middle of the century exceedingly high ozone mixing ratios will be commonplace, with extreme values well above $100 \mathrm{ppbv}$, 
especially in the Middle East. In Kuwait, for example, very high mixing ratios up to 200 ppbv are projected (Fig. 6). Since these high ozone mixing ratios typically occur during hot and stagnant weather conditions, we expect that photochemical air pollution will become an increasingly important confounding health risk factor during heat waves. It may be anticipated that the high ozone air pollution, for example, will be associated with significantly increased respiratory diseases and premature mortality (Lelieveld et al. 2013; Pozzer et al. 2012b).

Ideally, the atmospheric chemistry and climate simulations should be linked (Sect. 2). Projected climate change in the twenty-first century will likely be associated with increasingly stagnant weather conditions. Since surface ozone concentrations are correlated with temperature, a detrimental effect of warming is expected (Jacob and Winner 2009). The projected reduction in precipitation in most of the EMME will reduce the removal of particulate air pollution and increase fire events and air pollution. Nevertheless, a recent study of climate change effects on air pollution over the Iberian Peninsula indicates that the resulting increase in ozone in the twenty-first century (A2 scenario) is typically less than $10 \%$ (Jiménez-Guerrero et al. 2012). On the other hand, emissions of black carbon and the formation of tropospheric ozone can enhance climate warming. Further, aerosol pollution exerts a surface cooling, and the particles may nucleate more cloud droplets, which makes the clouds more reflective. The surface cooling decreases evaporation and thus slows down the hydrological cycle (Ramanathan and Feng 2009). In
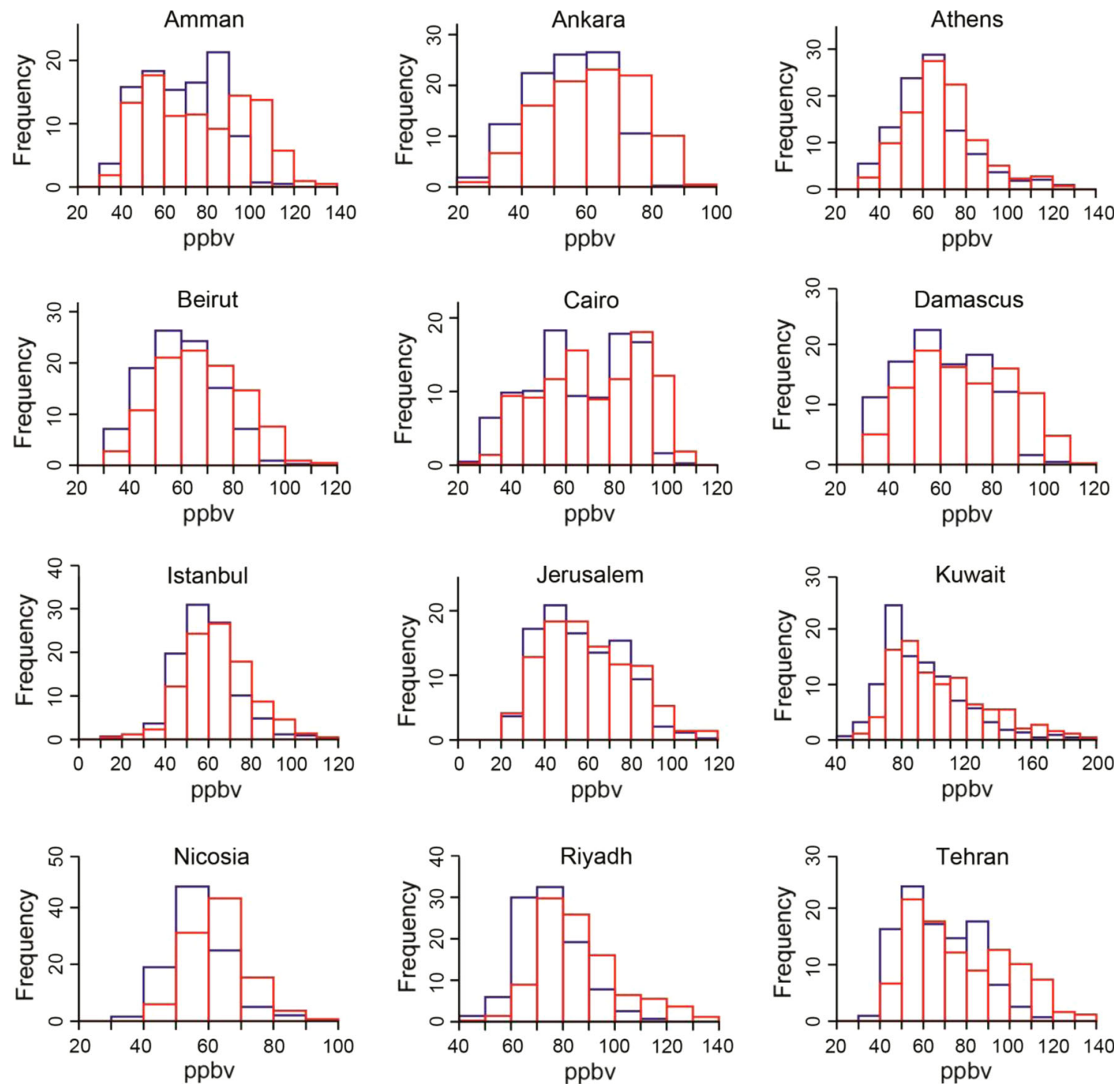

Fig. 6 Recent and mid-century ozone distributions. Model-calculated frequency histograms (\%) of ozone mixing ratios at the surface in summer (JJA). The blue diagrams indicate the reference calculation for the year 2005, and the red ones refer to the year 2050 
addition, feedbacks may exist between climate change and the emissions of dust and biogenic compounds with unknown consequences. In future, work will be interesting to account for these interactions between climate change and air pollution with online coupled regional air qualityclimate models, also accounting for vegetation and fire dynamics and desert dust emissions.

\section{Conclusions}

Our model results corroborate that climate change in the EMME is disproportionally precipitous. With 400 million inhabitants in two dozen countries, some with rapidly growing populations, the EMME may be one of the most populous areas on Earth to suffer severe impacts by climate change. In the northern EMME, a positive feedback between reduced cloudiness and rainfall and increased surface heat fluxes may accelerate climate warming during summer; though these results are to some degree model dependent and will need to be investigated further. In the southern EMME, summer temperatures are already high, and hot weather conditions are projected to increase importantly in the twenty-first century. Irrespective of the emission scenario considered (B2, A1B, A2), cities in the EMME will need to cope with strongly increasing heat extremes, and adaptation measures should be pursued. This may involve city planning, housing conditions, air conditioning and social factors (e.g., clothing). Typically, summer temperatures are expected to increase by $5^{\circ}-7^{\circ}$ by the end of the century, and in some cities increases up to $10{ }^{\circ} \mathrm{C}$ may occur, associated with very high numbers of heat wave days. Concurrently, increasing photochemical air pollution, associated with peak ozone levels in excess of $100 \mathrm{ppbv}$ and high concentrations of particulates by desert dust and anthropogenic aerosols, is expected to considerably reduce air quality during heat wave conditions. Considering the multiple environmental stresses in metropolitan areas, including confounding factors such as the urban heat island effect and growing air pollution, the cities in this region will become true hot spots of climate change.

Acknowledgments We thank the CIMME project team for the regional climate assessment (Climate change and Impacts in the Eastern Mediterranean and Middle East) and the Hadley Centre (UK) for providing the PRECIS model. This work contributes to the European Union project CIRCE. The research leading to these results has received funding from the European Research Council under the European Union's Seventh Framework Program (FP7/2007-2013)/ ERC grant agreement no 226144.

Open Access This article is distributed under the terms of the Creative Commons Attribution License which permits any use, distribution, and reproduction in any medium, provided the original author(s) and the source are credited.

\section{References}

Alpert P, Price C, Krichak SO, Ziv B, Saaroni H, Osetinsky I, Barkan J, Kishcha P (2005) Tropical tele-connections to the Mediterranean climate and weather. Adv Geosci 2:157-160

Anderson GB, Bell ML (2011) Heat waves in the United States: mortality risk during heat waves and effect modification by heat wave characteristics in 43 US communities. Environ Health Perspect 119:210-216

Basu R, Samet JM (2002) Relation between elevated ambient temperature and mortality: a review of the epidemiologic evidence. Epidemiol Rev 24:190-202

Battisti DS, Naylor RL (2009) Historical warnings of future food insecurity with unprecedented seasonal heat. Science 323: 240-244

Bengtsson L, Hodges KI, Roeckner E (2006) Storm tracks and climate change. J Clim 19:3518-3543

Beniston M, Stephenson DB, Christensen OB, Christopher A, Ferro AT, Frei C, Goyette S, Halsnaes K, Holt T, Jylhä K et al (2007) Future extreme events in European climate: an exploration of regional climate model projections. Clim Change 81:71-95

Chenoweth J, Hadjinicolaou P, Bruggeman A, Lelieveld J, Levin Z, Lange MA, Xoplaki E, Hadjikakou M (2011) The impact of climate change on the water resources of the eastern Mediterranean and Middle East region: modeled changes and socio-economic implications. Water Res Res 47:W06506. doi:10.1029/2010WR010269

Christensen JH, Hewitson B, Busuioc A, Chen A, Gao X, Held I, Jones R, Kolli RK, Kwon W-T, Laprise R et al (2007) Regional climate projections climate change 2007: the physical science basis. In: Solomon $\mathrm{S}$ et al (eds) Contribution of working group I to the 4th assessment report of the intergovernmental panel on climate change. Cambridge University Press, Cambridge, pp 847-940

Collins MB, Booth BB, Harris GR, Murphy JM, Sexton DMH, Webb MJ (2006) Towards quantifying uncertainty in transient climate change. Clim Dyn 27:127-147

Cox P, Betts RA, Bunton CB, Essery RLH, Rowntree PR, Smith J (1999) The impact of new land surface physics on the GCM simulation of climate and climate sensitivity. Clim Dyn 15:183-203

de Meij A, Pozzer A, Lelieveld J (2012) Trend analysis in aerosol optical depths and pollutant emission estimates between 2000 and 2009. Atmos Environ 51:75-85

Diffenbaugh NS, Pal JS, Giorgi F, Gao X (2007) Heat stress intensification in the Mediterranean climate change hotspot. Geophys Res Lett 34:L11706. doi:10.1029/2007GL030000

Efthymiadis D, Goodess CM, Jones PD (2011) Trends in Mediterranean gridded temperature extremes and large-scale circulation influences. Nat Hazards Earth Syst Sci 11:199-2214

Evans JP (2009) 21st century climate change in the Middle East. Clim Change 92:417-432

Evans JP (2010) Global warming impact on the dominant precipitation processes in the Middle East. Theor Appl Climatol 99:389-402

Fischer EM, Schär C (2010) Consistent geographical patterns of changes in high-impact European heatwaves. Nat Geosci 3:398-403

Fischer EM, Oleson KW, Lawrence DM (2012) Contrasting urban and rural stress responses to climate change. Geophys Res Lett 39:L03705. doi:10:1029/2011GL050576

Gao X, Giorgi F (2008) Increased aridity in the Mediterranean region under greenhouse forcing estimated from high resolution simulations with a regional climate model. Glob Planet Change 62:195-209

Giannakopoulos C, Le Sager P, Bindi M, Moriondo M, Kostopoulou E, Goodess CM (2009) Climatic changes and associated impacts in the Mediterranean resulting from a $2{ }^{\circ} \mathrm{C}$ global warming. Glob Planet Change 68:209-224 
Gualdi S, Somot S, May W, Castellari S, Déqué M, Adani M, Artale V, Bellucci A, Breitgand JS, Carillo A et al (2011) Future climate projections. In: Navarra A, Tubiana L (eds) Regional assessment of climate change in the Mediterranean. Springer, Dordrecht

Gurjar BR, Jain A, Sharma A, Agarwal A, Gupta P, Nagpure AS, Lelieveld J (2010) Human health risks in megacities due to air pollution. Atmos Environ 44:4606-4613

Haines A, Kovats RS, Campbell-Lendrum D, Corvalan C (2006) Climate change and human health: impacts, vulnerability, and mitigation. Lancet 367:2101-2109

Hirschi M, Seneviratne SI, Alexandrov V, Boberg F, Boroneant C, Christensen OB, Formayer H, Orlowsky B, Stepanek P (2011) Observational evidence for soil-moisture impact on hot extremes in southeastern Europe. Nat Geosci 4:17-21

IPCC 2007 Climate Change (2007) The physical science basis. In: Solomon $\mathrm{S}$ et al (eds) Contribution of working group I to the 4th assessment report of the intergovernmental panel on climate change. Cambridge University Press, Cambridge

Issar AS, Zohar M (2007) Climate change, environment and civilization in the Middle East. Springer, Berlin

Jacob DJ, Winner DA (2009) Effect of climate change on air quality. Atmos Environ 43:51-63

Jiménez-Guerrero P, Montávez JP, Gómez-Navarro JJ, Jerez S, Lorente-Plazas R (2012) Impacts of climate change on ground level gas-phase pollutants and aerosols in the Iberian Peninsula for the late XXI century. Atmos Environ 55:483-495

Jöckel P, Sander R, Kerkweg A, Tost H, Lelieveld J (2005) Technical note: the modular earth submodel system (MESSy) - a new approach towards earth system modeling. Atmos Chem Phys 5:433-444

Jöckel P, Tost H, Pozzer A, Brühl C, Buchholz J, Ganzeveld L, Hoor P, Lawrence Kerkweg A, Sander R et al (2006) The atmospheric chemistry general circulation model ECHAM5/MESSy: consistent simulation of ozone from the surface to the mesosphere. Atmos Chem Phys 6:5067-5104

Jones RG, Noguer M, Hassell D, Hudson D, Wilson S, Jenkins G, Mitchell J (2004) Generating high resolution climate change scenarios using PRECIS. Met Office Hadley Centre, Exeter

Kharin VV, Zwiers FW, Zhang X, Hegerl GC (2007) Changes in temperature and precipitation extremes in the IPCC ensemble of global coupled model simulations. J Clim 20:1419-1444

Kitoh A, Yatagai A, Alpert P (2008) First high-resolution model projection that the ancient "Fertile Crescent" will disappear in this century. Hydrol Res Lett 2:1-4

Kjellström E, Giorgi F (2010) Introduction to CR special issue 23: regional climate model evaluation and weighting. Clim Res 44:117-119

Klein Tank AMG, Zwiers FW, Zhang X (2009) Guidelines on analysis of extremes in a changing climate in support of informed decisions for adaptation, climate data and monitoring. WCDMP-No 72, WMO-TD No. 1500, WMO, Geneva

Klok EJ, Klein Tank AMG (2009) Updated and extended European dataset of daily climate observations. Int J Climatol 29:1182-1191

Knowlton K, Rosenthal JE, Hogrefe C, Lynn B, Gaffin S, Goldberg R, Rosenzweig C, Civerolo K, Ku J-Y, Kinney PL (2004) Assessing ozone-related health impacts under a changing climate. Environ Health Perspect 112:1557-1563

Knowlton K, Rotkin-Ellman M, King G, Margolis HG, Smith D, Solomon G, Trent R, English P (2009) The 2006 California heat wave: impacts on hospitalizations and emergency department visits. Environ Health Perspect 117:61-67

Krichak SO, Alpert P, Bassat K, Kunin P (2007) The surface climatology of the eastern Mediterranean region obtained in a three-member ensemble climate change simulation experiment. Adv Geosci 12:67-80
Krichak SO, Breitgand JS, Samuels R, Alpert P (2011) A doubleresolution transient RCM climate change simulation experiment for near-coastal eastern zone of the Eastern Mediterranean region. Theor Appl Climatol 103:167-195

Kuglitsch FG, Toreti A, Xoplaki E, Della-Marta PM, Zerefos CS, Türkeş M, Luterbacher J (2010) Heat wave changes in the eastern Mediterranean since 1960. Geophys Res Lett 37:L04802. doi:10.1029/2009GL041841

Langner J, Engardt M, Baklanov A, Christensen JH, Gauss M, Geels C, Hedegaard GB, Nuterman R, Simpson D, Soares J, Sofiev M, Wind P, Zakey A (2012) A multi-model study of impacts of climate change on surface ozone in Europe. Atmos Chem Phys 12:10423-10440

Lelieveld J, Hoor P, Jöckel P, Pozzer A, Hadjinicolaou P, Cammas J-P, Beirle S (2009) Severe ozone air pollution in the Persian Gulf region. Atmos Chem Phys 9:1393-1406

Lelieveld J, Hadjinicolaou P, Kostopoulou E, Chenoweth J, Giannakopoulos C, Hannides C, Lange MA, El Maayar M, Tanarthe M, Tyrlis E, Xoplaki E (2012) Climate change and impacts in the eastern Mediterranean and the Middle East. Clim Change 114:667-687

Lelieveld J, Barlas, C, Gianadaki D, Pozzer A (2013) Model calculated global, regional and megacity premature mortality due to air pollution by ozone and fine particulate matter. Atmos Chem Phys Discuss (accepted)

Lionello P, Malanotte-Rizzoli P, Boscolo R (eds) (2006) Mediterranean climate variability. Elsevier, Amsterdam

Liu C, Beirle S, Butler T, Liu J, Hoor P, Jöckel P, Pozzer A, Frankenberg C, Lawrence MG, Lelieveld J et al (2011) Application of SCIAMACHY and MOPITT CO total column measurements to evaluate model results over biomass burning regions and Eastern China. Atmos Chem Phys 11:6083-6114

Meehl GA, Tebaldi C (2004) More intense, more frequent, and longer lasting heat waves in the 21st Century. Science 305:994-997

Meehl GA, Stocker TF, Collins WD, Friedlingstein P, Gaye AT, Gregory JM, Kitoh A, Knutti R, Murphy JM, Noda A et al (2007) Global climate projections climate change 2007: the physical science basis. In: Solomon S et al (eds) Contribution of working group I to the 4th assessment report of the intergovernmental panel on climate change. Cambridge University Press, Cambridge, pp 747-845

Mitchell TD, Jones PJD (2005) An improved method of constructing a database of monthly climate observations and associated highresolution grids. Int J Climatol 25:693-712

Nakićenović N, Swart R (eds) (2000) IPCC special report on emissions scenarios. A special report of working group III of the intergovernmental panel on climate change. Cambridge University Press, Cambridge

Önol B, Semazzi FHM (2009) Regionalization of climate change simulations over the eastern Mediterranean. J Clim 22:19441961

Papadimas CD, Hatzianastassiou N, Mihalopoulos N, Kanakidou M, Katsoulis BD, Vardavas I (2009) Assessment of the MODIS collections C005 and C004 aerosol optical depth products over the Mediterranean basin. Atmos Chem Phys 9:2987-2999

Pozzer A, Jöckel P, Tost H, Sander R, Ganzeveld L, Kerkweg A, Lelieveld J (2007) Simulating organic species with the global atmospheric chemistry general circulation model ECHAM5/ MESSy1: a comparison of model results with observations. Atmos Chem Phys 7:2527-2550

Pozzer A, Pollmann J, Taraborrelli D, Jöckel P, Helmig D, Tans P, Hueber J, Lelieveld J (2010) Observed and simulated global distribution and budget of atmospheric C2-C5 alkanes. Atmos Chem Phys 10:4403-4422

Pozzer A, de Meij A, Pringle KJ, Tost H, Doering UM, van Aardenne J, Lelieveld J (2012a) Distributions and regional budgets of 
aerosols and their precursors simulated with the EMAC chemistry-climate model. Atmos Chem Phys 12:961-987

Pozzer A, Zimmermann P, Doering UM, van Aardenne J, Tost H, Dentener F, Janssens-Maenhout G, Lelieveld J (2012b) Effects of business-as-usual anthropogenic emissions on air quality. Atmos Chem Phys 12:6915-6937

Pringle KJ, Tost H, Metzger S, Steil B, Giannadaki D, Nenes A, Fountoukis C, Stier P, Vignati E, Lelieveld J (2010) Description and evaluation of GMXe: a new aerosol submodel for global simulations (v1). Geosci Model Dev 3:391-412

Ramanathan V, Feng Y (2009) Air pollution, greenhouse gases and climate change: global and regional perspectives. Atmos Environ 43:37-50

Robine JM, Cheung SLK, Le Roy S, van Oyen H, Griffiths C, Michel J-P, Herrmann FR (2006) Death toll exceeded 70,000 in Europe during the summer of 2003. C R Biol 331:171-178

Rodwell MJ, Hoskins BJ (1996) Monsoons and the dynamics of deserts. Q J R Meteorol Soc 122:1385-1404

Roeckner E, Brokopf R, Esch M, Giorgetta M, Hagemann S, Kornblueh L, Manzini E, Schlese U, Schulzweida U (2006) Sensitivity of simulated climate to horizontal and vertical resolution in the ECHAM5 atmosphere model. J Clim 19:3771-3791

Sander R, Jöckel P, Kerkweg A, Lelieveld J (2005) Technical note: the new comprehensive atmospheric chemistry module MECCA. Atmos Chem Phys 5:445-450

Schär C, Vidale PL, Lüthi D, Frei C, Häberli C, Liniger MA, Appenzeller C (2004) The role of increasing temperature variability in European summer heatwaves. Nature 427:332-336

Seneviratne SI, Corti T, Davin EL, Hirschi M, Jaeger EB, Lehner I, Orlowsky B, Teuling AJ (2010) Investigating soil moistureclimate interactions in a changing climate: a review. Earth Sci Rev 99:125-161

Shindell D, Kuylenstierna JCI, Vignati E, van Dingenen R, Amann M, Klimont Z, Anenberg SC, Muller N, Janssens-Maenhout G, Raes F, Schwartz J, Faluvegi G, Pozzoli L, Kupiainen K, HöglundIsaksson L, Emberson L, Streets D, Ramanathan V, Hicks K, Oanh NTK, Milly G, Williams M, Demkine V, Fowler D (2012) Simultaneously mitigating near-term climate change and improving human health and food security. Science 335:183-189

Smiatek G, Kunstmann H, Heckl A (2011) High-resolution climate change simulations for the Jordan River area. J Geophys Res 116:D16111. doi:10.1029/2010JD015313

Smoydzin L, Fnais M, Lelieveld J (2012) Ozone pollution over the Arabian Gulf-role of meteorological conditions. Atmos Chem Phys Discuss 12:6331-6361

Tai APK, Mickley LJ, Jacob DJ (2012) Impact of 2000-2050 climate change on fine particulate matter $\left(\mathrm{PM}_{2.5}\right)$ air quality inferred from a multi-model analysis of meteorological modes. Atmos Chem Phys 12:11329-11337

Tanarhte M, Hadjinicolaou P, Lelieveld J (2012) Intercomparison of temperature and precipitation datasets based on observations in the Mediterranean and the Middle East. J Geophys Res 117: D12102. doi:10.1029/2011JD017293

Tost H, Jöckel P, Kerkweg A, Pozzer A, Sander R, Lelieveld J (2007) Global cloud and precipitation chemistry and wet deposition: tropospheric model simulations with ECHAM5/MESSy1. Atmos Chem Phys 7:2733-2757

Trigo IF, Davies TD, Bigg GR (2000) Decline in Mediterranean rainfall caused by weakening of Mediterranean cyclones. Geophys Res Lett 27:2913-2916

Tyrlis E, Steil B, Lelieveld J (2013) The summer circulation in the eastern Mediterranean and the Middle East: influence of the South Asian monsoon. Clim Dyn 40:1103-1123

Ulbrich U, Leckebusch GC, Pinto JG (2009) Extratropical cyclones in the present and future climate: a review. Theor Appl Climatol 96:117-131

Vandentorren S, Bretin P, Zeghnoun A, Mandereau-Bruno L, Croisier A, Cochet C, Ribéron J, Siberan I, Declercq B, Ledrans M (2006) August 2003 heat wave in France: risk factors for death of elderly people living at home. Eur J Publ Health 16:583-591

Vautard R, Yiou P, D'Andrea F, de Noblet N, Viovy N, Cassou C, Polcher J, Ciais P, Kageyama M, Fan Y (2007) Summertime European heat and drought waves induced by wintertime Mediterranean rainfall deficit. Geophys Res Lett 34:L07711. doi: 10.1029/2006GL028001

Young PJ, Archibald AT, Bowman KW, Lamarque J-F, Naik V, Stevenson DS, Tilmes S, Voulgarakis A, Wild O, Bergmann D, Cameron-Smith P, Cionni I, Collins WJ, Dalsøren SB, Doherty RM, Eyring V, Faluvegi G, Horowitz LW, Josse B, Lee YH, MacKenzie IA, Nagashima T, Plummer DA, Righi M, Rumbold ST, Skeie RB, Shindell DT, Strode SA, Sudo K, Szopa S, Zeng G (2013) Pre-industrial to end 21st century projections of tropospheric ozone from the Atmospheric Chemistry and Climate Model Intercomparison Project (ACCMIP). Atmos Chem Phys 13:2063-2090

Zhang X, Aguilar E, Sensoy S, Melkonyan H, Tagiyeva U, Ahmed N, Kutaladze N, Rahimzadeh F, Taghipour A, Hantosh TH et al (2005) Trends in Middle East climate extreme indices from 1950 to 2003. J Geophys Res 110:D22104. doi:10.1029/2005JD006181

Zittis G, Hadjinicolaou P, Lelieveld J (2013) Role of soil moisture in the amplification of climate warming in the Eastern Mediterranean and Middle East. Int J Clim Change (submitted) 